doi: 10.52370/TISC21162DD

\title{
BRANDING OF STATES AND NATIONS IN (POST) COVID 19 ERA
}

\author{
Dejan Dašićc ; Boban Dašić ${ }^{2}$
}

\begin{abstract}
The subject of this paper is the COVID-19 pandemic impact on nations and states branding. Nations branding is very important for their global position. That is why there are numerous specific ways for state branding: film industry, sports events, civil engineering ventures, cultural and public events, diplomacy, celebrities, public relations, tourism etc. In general, people know very little or nothing about individual nations and states, so sports and tourism, as globally popular advents, may represent extraordinary set for their promotion. Globalism is a process of whose activities no state or person is spared. It is followed with numerous advantages but with numerous menaces too. With one of them, the world is struggling these days - the COVID-19 pandemic. Sports events all around the world are postponed or canceled in an effort to stop the virus from spreading. Pandemic and counties lockdowns almost killed global tourism.
\end{abstract}

Key Words: Brand, nations branding, image, COVID-19 JEL classification: $I 15, Z 32$

\section{Introduction}

Nations branding is a relatively new concept. It is the process of applying corporate branding techniques to promote countries or nations, although some authors (Fan, 2006, p. 5) remind that a distinction should be made between the branding of nations and states. The main objective is to build and manage the reputation of a state. Simon Anholt (2007) was one of the very first authors who noticed the importance of national branding and its

\footnotetext{
${ }^{1}$ Dejan Dašić, PhD, Associate Professor, Alfa University, Faculty of Finance, Banking and Auditing, Belgrade, +381606626922, dejan.dasic@alfa.edu.rs

2 Boban Dašić, PhD, Professor, Alfa University, Faculty of Finance, Banking and Auditing, Belgrade, +381656265211, bobandasickg@gmail.com
} 
effects. He designed a method for evaluation of national brand effectiveness, a global survey known as Anholt-Gfk Roper Nations Brand Index. The Nation Brand Index represents the average value of ratings on various criteria: people, governance, exports, tourism, culture and heritage, as well as investment and immigration.

There are many reasons why countries should manage their branding and one is the need for attracting tourists and investments. To be successful in the dynamic tourist market, a country has to be focused and specific about possible achievements and whom it wants to attract. This way a country becomes a tourist destination and the general country branding shifts its focus on a country destination branding and tourists as the target group (Kos-Kavran \& Herman, 2020).

A positive and stable image is something that helps the place to differ from its surroundings and thus be more attractive to its inhabitants, but to visitors and tourists too. The positive image of the destination is a combination of skillful handling of marketing tools and a sincerely shared care for people. It is an endless process, because the image of the city can be constantly worked on and improved, or moved in another direction. At the same time, it is a very fragile matter, because any negative connotation in connection with the place or its surroundings remains in the subconscious of citizens for a very long time and it is difficult to correct it (Radanović et al., 2020).

Through the branding process, a nation improves its reputation and perception, enabling it to attract foreign direct investment while making it an ideal destination for tourism and trade (Mugo \& Misiani, 2017). Although there are many challenges, there are also many advantages why the nation and/or country branding needs to be managed strategically and systematically in the long term, as it had already been said. The main advantages can be eliminating negative stereotypes (Dašić, 2015), creating a positive image, achieving desired and possible world reputation and influence in today's and future international relations, building and maintaining tourist attractiveness for a specific group of tourists (Dašić et al., 2020a). One must keep in mind that in contemporary society brands can spur affinity or discrimination, helping define both individual and collective identities (Saviola \& Marazza, 2013). It is important to know the perception of the nation and the causes of it for proper construction and management of a nation brand. Brand perception depends on numerous factors and dimensions (Vranešević et al., 2020, p. 65). 
Place branding means the actual delimitations of a place and the determination of its dominants to fully reflect its good image. Place branding aims to attract customers, tourists, investors, new residents. A positive and stable image is something that helps the place to differ from its surroundings and thus be more attractive to its inhabitants, but also to visitors and tourists. The positive image of the place is a combination of skillful handling of marketing tools and a sincerely shared subconscious of people. It is an endless process, because the image of the city can be constantly worked on and improved, or moved in another direction. At the same time, it is a very fragile matter, because any negative connotation in connection with the city or its surroundings remains in the subconscious of citizens for a very long time and it is difficult to correct it (Radanović et al., 2020).

Regardless of the models or forms, the success of state (destination) branding depends on three crucial factors (Cotirlea, 2015):

- the importance of highlighting the unique elements of the region's attractiveness and its specific competitive advantages

- investments in public sphere (in order to visualize the brand of the region)

- and intensive process of internal marketing before external

Branding process helps the state to define self-identity, to promote, attract attention and differs from others. In order to become strong brand state needs willing residents. In general, in the base of state branding are ambiguous and visionary governing bodies that perceive the branding process as a strategic and economic need. A state can be branded in numerous ways: as a touristic destination, as a trading or economic center, as a calm and peaceful place etc.

One of the common brand definitions: "A brand represents a name, term, design, symbol or other characteristic which identify good or service of one vendor and distinguishes it from others" (Acer \& Joachimshaler, 2009). Branding, as a discipline, originates from the late 19th century and nowadays it spreads on education, sports, fashion, traveling, art, literature, humanitarian organizations, individuals, states etc. (Dašić, 2013; Dašić, 2016). The essence of the branding is to make the product, service, person, destination recognizable in the consumers' eyes.

In the very beginning of the 21 st century problems for tourism has begun. Ecological catastrophes, financial crisis, political disturbances, wars and growing threats of terrorism have left their mark on the last decade. The 
migrant crisis has particularly clearly highlighted the difference between desirable foreigners - tourists and undesirable foreigners - poor migrants (Prnjat, 2019). That crisis was only temporarily removed from the agenda of major media outlets due to the crisis with the COVID 19. The influence of such crises is especially remarkable in our hypermobile, integrated world and in an increasing number of tourism dependent locations. As an example, volcanic ash cloud from Ejafjadlajekidt volcanic eruption in Island, costed worlds industry 1.7 billion \$ in 2010 (Ellertsdottir, 2014). COVID-19 pandemic has affected all areas of life, so sport is no exception. The sports industry is facing the biggest crisis since the end of World War II. In order to protect the health of athletes and spectators, as well as all other participants, a large number of sport events at all levels (local, regional, national and international) have been canceled or postponed. In early COVID 19 days, global sport activities almost ceased. Sports activities were launched at home using the Internet and virtual networks. Competitions were stopped and clubs were closed. Sports production was in crisis. (The Impact of the Covid Crisis on the Sport Industry).

\section{Examples of country branding}

Vietor $(2010,1)$ states that nowdays every country competes, implicitly or explicitly, for the share in worlds economy, fighting for foreign investments and export through their activities. "Therefore, one of the important aims of national economic and FDI (Foreign Direct Investments) policies should be improvement of participation of FDI" (Jovović, et all., 2014, p. 466). There is a need for higher level of FDI in order to "use potential positive effect as well as recognition of these potential benefits from FDI" (Stojadinović-Jovanović \& Dašić, 2015, p. 661). In line with the motto "learn from the best" or, to paraphrased Tolstoy: "All happy countries are alike ..." good practice may be used for comparative analyses in order to discover new possibilities and for the benchmarking whenever the main infrastructure of noted branding potentials and relevant macro indicators of two states matches.

Woli Olins and Jeremy Hildret (2015) ask in their work "State Branding: yesterday, today, tomorrow" if it is possible to use the same techniques in branding nations, goods and companies. They stated that nations branding is not the same as companies branding, but they noted people could be motivate, inspire and lead in the same way, using the same techniques. During the process of improving their image in the world, Spain and Australia have managed to set significant number of brands. 
One of the most interesting places for marketing is the state's endeavor to attract new investments and factories. Whenever some company starts a selection process for choosing a country, region or destination for investment they are gathering information about potential candidates labor, taxes, energy laws, communications and business, schools and high education. It was the latter that was crucial for Costa Rica- high level of technical education and significant number of electronics companies have influenced the arrival of investors (Kotler \& Gartner, 2015).

An increasing number of countries pay attention to the branding of their country and invest significant resources in maintaining their own image and reputation. Many countries have realized the role of the global image in attracting the attention of international organizations, investments, technical assistance, as well as trade partners, investment bankers and tourists. One of them is Spain. Positioning the nation as a global brand is becoming more and more recognized and useful for both small and large countries, and it is believed that building the nation's capital requires time, money and a lot of work. Spain example best leads to the conclusion that the implementation of a strong state branding strategy directly affects the improvement of the nation's image in the world. In its branding strategy, Spain attaches importance to culture, football, tennis, archeological sites, but has a focus on medicine, as well as the economy in terms of investment. The logo of the national brand of Spain is the coat of arms with a message in their language "Brand of Spain". Some magazines put the national brand logo next to the name. Their message is recognizable and reads "we are well known around the world anyway", so for these reasons they believe that they do not need branding (Pavićević et al., 2020).

Although the economic crash may have brought the country low with the consequences still reechoing it has nevertheless but offered an opportunity. Further it has made the country cheaper to visit and invest in, and easier to export from. There was a steadily increase of the number of foreign tourists with the country repowering its potential. Such favourable conditions brought a rapid growth rate over the past decade especially in tourism, which is one of the means through which the country is marketed to outsiders and among the economy's largest sectors. It is thought that over two million tourists were annually entering the country following the crash, and by 2010 over five million were believed to have visited (Macmillen, 2011). 
One case study of Croatia (Kos-Karavan \& Herman, 2020) showed how a country can work on its brand identity through the years. Croatia's first brand communication focus was on the rich history and experiences on the Adriatic coast. The tourists were intrigued by this idea that Croatia is a country where they can escape and enjoy the beauties of the Croatian coast. But as other parts of Croatia had much more to offer, the Croats were not happy with this strategy. So National Tourist Board shifted brand communication strategy to a tourism that is non-seasonal, focusing on all parts of the Croatia and other specific forms of tourism, not just sun and the sea. German media presented Croatia as a safe destination and the sentiment of their online articles was mostly positive. Slovenian media published the most articles and the sentiment of their online articles was mostly positive too. Austrian media presented Croatia as a cheap destination with crowded but beautiful coast. The sentiment analysis of online articles in Austrian media revealed that the most published articles fell into the positive or neutral categories.

A small country in the middle of Europe with a rich history, a large number of historically and artistically important peculiarities, with many cultural sights and monuments, a picturesque landscape, a specific language, rich cuisine, beautiful women and excellent beer. Thus, the Czech Republic could be characterized as a tourist destination. For several years now, the Czech Republic has been striving for its position in the increasingly competitive market of European countries and regions. However, over the years, the possibilities of tourism have developed and new tourism products have emerged, such as cycling, agro tourism, urban, congress, incentive, cultural or ecological tourism. The Czech Republic brand and its nation branding have a long history. After the division of the country into the Czech Republic and Slovakia, the country faced the difficult task of creating a separate destination brand. This was followed by a series of unsuccessful attempts to create a suitable destination logo that would best describe and informal represent the Czech Republic. However, the logo itself is insufficient for the process of presenting the destination mark. First of all, it is necessary to create an appropriate marketing strategy, which will be based on national values and specific goals. The logo, together with a unified visual style, can help the brand build a positive image (Horáčková et al., 2020).

The advantage of "sea, sand and sun" although still important are not guarantee for successful season because tourists are less willing to accept standard packages. Montenegro may and should take advantage of its 
natural resources for the purpose of developing sports and recreational tourism and at the same time brand itself as a country with good touristic offer $f$ that kind. Natural environment in Montenegro represents an attractive and hidden destination for tourists looking for an active holiday. Numerous natural beauties, sea and mountains vicinity are huge potential for branding Montenegro as a desirable touristic destination. Investments in recreational tourism in natural environment (relative to anthropogenic) are not significant but mainly based on marketing support. National tourist organization of Montenegro has done a lot on Montenegro image promoting based on variety of natural values so that sport and recreation tourism slowly taking their rightful place (Marijanović et al. 2020).

The image of a state is greatly affected by tourism, i.e., tourists visiting certain destinations in that country. Therefore, all tourism developed countries and those that strive to become one take great care to improve their image. That is why one of the most important areas of destination management is research and creation of the image of the destination. One study (Konečnik-Ruzijer, 2015, 351) lists two aspects that have played a decisive role in Slovenia's branding: its history (although it is a new state) and its rich geographical, historical and cultural diversity. Although the initial goal of brand development was to present the visual elements of logos and slogans, such as "I Feel Slovenia" (Figure 1), the author of this text concludes that in order for branding to be successful, continuity, political will and support of all Slovenian citizens are necessary.

Figure 1: Logo and slogan of Slovenia

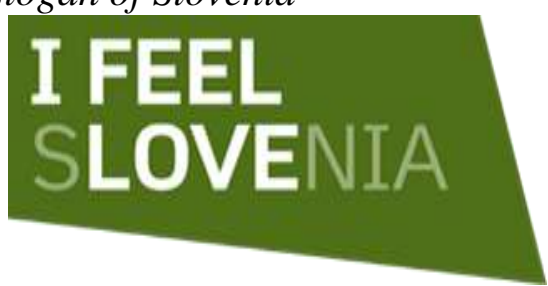

Source: Logovectordr.com, http://logovectordl.com/i-feel-slovenia-logovector-svg/, (18 February 2021)

\section{State and nation branding platform through sport}

National branding is highly important for the position of a nation in the world. People generally know little about individual countries and nations, and sport as an area that is popular globally, is an excellent means of promotion. On the other hand, sport today is a big business in which there 
are more and more examples where rich sheiks from the Middle East buy one club at a time in the Premier League of England. In addition to buying leading American industrial brands, Chinese billionaires are increasingly buying basketball, rugby and American football clubs. These, and many other examples, indicate globalization in the market of sports products and services, and we can say that one of the basic marketing trends is the global orientation. It involves looking at the whole world as a possible market. This marketing strategy involves identifying target groups in the global market, as well as responding to market opportunities in the global environment (Ratković \& Dašić, 2018).

Sportsmen i.e., athletes, with their success influence the creation of a positive image of the state and the nation on a global level. Consequently, this affects the creation of a better economic position of the country where the athletes come from, and can also affect the improvement of image, investment and business cooperation (Aziz et al., 2012). That is why, due to the growing profits in the sports industry and the popularity of sports on a global level, there is no industry that is not interested in cooperation with the sports industry.

Sport has a great cultural and economic significance. It has long since sport ceased to be just a competition. Today it is one of the main ways of branding nations and states. The sports industry continues to grow and globalize, and sport events offer a great opportunity for countries to be at the center of media attention for a short period of time. A well-known sportsman can easily be transferred to the brand of the product, and the significant link to brand of the whole nation. Regions, states, nations, and even entire continents are actively competing in promotion, with one goal, to develop a positive association to a particular destination that just gets the organization of a certain sporting competition. Organization of the Olympic Games, World Football, Basketball and other championships, similar international competitions is becoming a powerful economic driver of the host country. Organizing sports events can be a good economic support during and after the sports event for the host country. Along with this process, the sports industry in the countries of the organizer and the winner takes an even better position. Strengthening the national image based on sport success, whether it is a successful organization of a global sports event, or individual and team success of sportspeople, is a very desirable way of branding in a modern environment (Dašić \& Jović-Bogdanović, 2020). 
Skoko claims that during the great sports events, not only are the countries organizers (hosts) making profit, but also the countries participating in the competition. The sports stage is one of the most popular and far-reaching promotional channels, and sport events, in addition to providing impressive images thanks to the competitive spirit, create emotional connections between viewers around the world (Skoko, 2009, p. 162).

The brands produced in a particular country are foundation of branding itself, but natural, historical, cultural, anthropogenic and other resources of the destination or people living in that climate are also used for that purpose. The branding process itself implies longevity, in correlation with that, the strategies that need to be defined must have continuity over time, until the moment when the need for their change arises, and then they continue to live in accordance with the new goals. The success of destination branding depends on the appropriate choice of marketing elements with a focus on those in the field of communication, and in relation to the chosen approach to the application of this process. Accordingly, we list three possibilities of the branding platform of states and nations through sport (Rein \& Shields, 2007):

1. The event (organization of the Olympic Games, football, basketball and other world championships),

2. The team (branding through world-renowned teams like Manchester United, or Toronto and Montreal with their hockey teams), and

3. The place (Dubai that has transformed from a large oil producer into a very desirable and attractive tourist destination, where a variety of sports activities takes place).

Sports events around the world are being postponed or cancelled in order to prevent the corona virus from spreading. Numerous national football federations have suspended their professional seasons 2019-2020 and will not declare a winner; UEFA has postponed EURO 2020 until the summer of 2021. Formula 1 has postponed numerous races in 2019 and 2020. Similarly, the famous Wimbledon tennis tournament was cancelled for the first time since 1945, and the International Olympic Committee decided to postpone the Olympic Games planned to be held in Tokyo in 2020, until the summer of 2021 (Dašić et al., 2020b). Taking into account all the above, depending on the long-term impact of COVID-19 on the economy, individual sponsors may be forced to terminate sponsorship agreements. "For example, it was announced that Adidas and Emirates, the two main sponsors of the Real Madrid football team, faced critical financial difficulties. As a result, their national governments provided them financial 
support to enable them to continue running their business as before" (Dašić, et al., 2020c, p. 54).

The various impacts of the pandemic on sport have required sports organizations to take new approaches to emerging crisis managment. "Firefighting" enriched global knowledge of sports management and generate new, fresh ideas (Keshkar et al., 2021).

Sport can be one of the most important drivers of economic development of countries. The sports industry is globally influencing the creation of an increasing number of new jobs. In 2000, Adidas had slightly more than 12.000 employees, and in 2016, that number was already over 60.000. It is similar with other global sports brands (Ratković \& Dašić, 2018). The importance of sports for branding countries and nations is best illustrated by the following example. The international popularity of the Premier League is higher than ever before, with 64 players of different nationalities, and it is thought to be close to being watched by 4 billion people. This is a really big global phenomenon, the top sports league. The mere fact that 188 countries and 212 territories around the world have the right to broadcast football matches in this league, talks enough about the promotional potential of this league. English Premier League is the strongest in the world on many aspects, which uses its marketing potential to attract a large number of people to visit England. (Dašić \& Jović-Bogdanović, 2020). Also, many successful Premier League football teams are very successful in branding their country. The issue of the value of the brand is gaining an important and noticeable place in the value structure of each company, so it is therefore necessary to know its strength and financial value.

By cancelling or postponing almost all sport events, advertisers and sponsors are trying to see if they have the appropriate contractual rights to protect themselves, now that they have lost the initiative in their media plans. Depending on the contracts contents it will be decided whether the advertiser should withdraw or pause contract obligations and financial investments that were reserved for sport events that will never happen. However, acting according to these contracts is not simple, as some advertisers have unfortunately already discovered. Many companies that advertise in sports use the "force majeure" clause as a way to get back the money that was originally spent on ads during sporting events. "Force majeure" clauses are standard in many legal contracts from a variety of industries (not just sports), unless you are in an industry prone to being disrupted by natural disasters (Marcus, 2020). 


\section{State and nation branding platform through tourism}

The global market for place branding has never been more competitive. Places both established and new, are under increasing pressure to attract and retain residents, tourists and investors to a market of accelerated globalization and fragmentation. In that sense, Kotler and Gertner (2015) state that when it comes to attracting tourists, investors, population and events, the competition between different places has changed a lot. In the past, several cities or regions had a "deed" on the selection of tourists (Paris, London, New York, USA, Europe...), but times are slowly changing.

Tourism is becoming increasingly popular. Today, it provides tourists with a wide selection of tourist destinations that they can visit. This creates a significant competition between individual countries and regions, the aim of which is to attract not only tourists but also foreign investors. Individual countries thus function as brands that present their cultural, natural, historical or other products in order to create a strong brand that will ensure the country a strong position in a competitive market and help the country attract foreign tourists (Horáčková et al., 2020).

Tourism as an industry has almost died away due to the global pandemic. Countries around the world have introduced lockdowns with human mobility being restricted. The top destinations in the world China, Italy, Spain, USA, Mexico, faced huge economic losses in tourism. Recently many countries have gradually started opening up their destinations or are making promotions of them. Principally they should promote those destinations with safety measures for both employees and guests.

Although tourism is an industry which fills people with enthusiasm and happiness it is not self-sufficient since it is, directly or indirectly, dependent on and connected with many other industries. Tourism is not possible without transportation systems, hotels, and other tourism service providers. Due to the COVID-19 situation the hotels have been empty and flights cancelled those employed in tourism industry are losing jobs or facing salary shortages. (Sultana, et al., 2020).

Sports tourism significantly contributes to the existing and potential tourism development. Numerous examples have shown that sports tourism has significant economic effects, in the form of additional income, income from tickets, tourist income, etc. Sports events carry with them infrastructure improvement, that is, they bring rich investments that further 
bring great profits. In addition to numerous sports facilities, many other infrastructure facilities are being built for tourist purposes. Sport manifestations raise satisfaction of local population by increasing employment, engaging in organization, maintaining and controlling the event (Dašić \& Jović-Bogdanović, 2020, 108).

The latest data show that hotel occupancy rates in the USA are below 20\%, while plane travels are almost $95 \%$ less in comparison to the same period 2019 (Cooper \& Asmelash, 2020). According to the World Travel and Tourism Council (WTTC) one in every ten jobs (estimated 330 millions) is directly supported or influenced by travel or tourism related activities. The tourism industry itself is estimated to be worth about $\$ 7$ trillion. Therefore, it is considered as one of the world's largest economic sectors. Although known for its resilience, the tourism industry could not avoid the impact of the COVID 19 pandemic crisis, which the chief economist of the International Monetary Fund (IMF) called "a crisis like no other" (Keshkar et al., 2021).

The world has experienced many epidemics and pandemics throughout history, but none has had as pronounced consequences for the global economy as the COVID-19 pandemic. In a short period, COVID 19 caused panic around the world. Various restrictive measures have been taken to prevent the virus spreading - transport of people and goods has been minimized, state borders have been closed... Restrictive measures may have had a positive impact on human health, but also a huge negative impact on the global economy, especially in tourism. "It is estimated that in 2020 a large drop in international tourist arrivals will reduce global tourism industry revenue by almost $70 \%$. Thus, COVID-19 is not only a danger to human life, but also has numerous short-term and long-term negative economic, social and environmental consequences. The impact of COVID-19 on tourism in developing countries is projected to be significantly greater than in developed countries. In some smaller countries where tourism accounts for more than 50\% of GDP (e.g., Maldives and Seychelles) the pandemic has pushed a large part of population to poverty since the tourism is a primary source of income in these countries" (Luković \& Stojković, 2020, p. 85).

Tourism in the Latin American and Caribbean region has almost died out due to the COVID-19 pandemic. Half of Latin America's and Caribbean services exports belongs to truism and represent a significant share of gross domestic product (GDP) and employment rates. Knowing that it is clear 
how hard their economy has been affected. At the same time, not only the state is affected, but also numerous local communities. "An impact scenario shows that the slump in tourism may cause total GDP growth in the Caribbean and Latin America to fall by 8 percentage points and 1 percentage point, respectively, while total employment could potentially decline by 7 percentage points in the Caribbean and 1 percentage point in Latin America" (Mulder, 2021, p. 7).

The economic, social and labour crisis occurred due to the global COVID19 pandemic has already affected the supply and demand chain. Thus, the global tourism industry is likely to be more endangered than ever with longlasting consequences. It is time to reassess and transform the sustainability of the overall tourism sector. Furthermore, after the pandemic, the most essential thing is to return the business in a normal condition and try to protect itself and the employees. The tourism industry needs a plan for the revival (Deb \& Nafi, 2020).

\section{Conclusion}

When a certain progress is reached in the process of states or nations branding, there is a change of opinion regarding one country in a positive context. This opinion not only must be maintained, but it is also required to constantly and continuously improve and strengthen it with positive messages. Numerous countries apply required measures regarding quarantine and social distance in order to suppress the pandemic. Global pandemic of corona virus has resulted in big changes in implementation of planned strategies of branding states and nations, forcing people from marketing to reconsider their thinking about current and future marketing campaigns. Due to pandemic, many jobs at global level are jeopardized, not only in marketing and strategy dealing with building positive image of states and nations, but with retail chains and sport services industry, including travelling, tourism, infrastructure, transport, catering, media broadcasting etc. It is not uncommon to hear that after COVID 19 pandemic, nothing will be the same. Taking into consideration the data mentioned in the paper, it is still not quite clear in which way many states will overcome the problems caused by COVID 19 pandemic, as well as whether bright future is there for tourism and sport in the post COVID 19 era.

In addition to a rather bad impact on health due to inactivity, risks for mental health related to loneliness and anxiety, COVID 19 pandemic will 
also have rather long-term consequences for everyday life, public health, economy sectors, particularly service sectors (tourism), food and accommodation services, transport, sport, etc. Sport events throughout the world are being either delayed or cancelled as an attempt to stop spreading corona virus. Sport and sportsmen with their successes affect the creation of a positive image of a state and a nation at a global level. Not less significant, sport tourism contributes to the existing and potential tourism development, but it also affects the state and nation global image and has significant economic effects

\section{References}

1. Acer, D.A., Joachimshaler, E. (2009). Brend Leadership, Simon and Schuster, United Kingdom.

2. Anholt, S. (2007). Competitive Identity, Palgrave Macmillan, New York.

3. Aziz, N., Kefallonitis E., Friedman B. (2012). Turkey as a Destination Brand: Perceptions of United States Visitors. American International Journal of Contemporary Research, Vol. 2, No. 9, 211-221.

4. Cooper, A., Asmelash, L. (2020). Nearly 80\% of hotel rooms in the US are empty, according to new data, CNN.com, https://edition.cnn.com/2020/ 04/08/us/hotel-rooms-industry-coronavirus-trnd/index.html, (01 March 2021).

5. Cotirlea, D.A. (2015). Country image vs. country brand: differences and similarities. Ecoforum, Vol. 4, S.I. 1, 165-171.

6. Dašić, D. (2013). Brendiranje država i nacija. Kultura, No. 139, 396415.

7. Dašić, D. (2015). Cinematography as a tool of creating negative stereotypes about the Serbs. Sociološki pregled, Vol. 49, No. 1, 25-46.

8. Dašić, D. (2016). Brendiranje mesta i/ili destinacija. Kultura, No. 152. 377- 393.

9. Dašić, D. Tošić, M., Deletić, V. (2020b). The impact of the COVID-19 pandemic on the advertising and sponsorship industry in sport. BizInfo, Vol. 11, No. 2, 105-116. 
10. Dašić, D., Jović-Bogdanović, A. (2020). Sport as a cenntral component of the country and nation branding strategy. In M. Ratković \& N. Perić (Eds.), Branding of states and nations, possibilities and implications (pp. 94-113). Faculty of Business Studies and Law, Faculty of Strategic and Operational Management, Belgrade.

11. Dašić, D., Živković, D., Vujić, T. (2020a). Rural tourism in development function of rural areas in Serbia. Economics of Agriculture, Vol. 67, No. 3, 719-733.

12. Deb, S.K., Nafi, S.M. (2020). Impact of covid-19 pandemic on tourism: recory proposal for future tourism. GeoJournal of Tourism and Geosites, Vol. 33, No. 4, 1486-1492.

13. Ellertsdottir, E.T. (2014). Eyafjallaokull and the closure of European airspace: crisis management, economic impact, andackling future risks. The student economic review. vol. XXVIII, 129-137. https://www.tcd.ie/ Economics/assets/pdf/SER/2014/elin_thora.pdf (13. March.2021)

14. Fan, Y., (2006). Branding for nation: what is being branded? Journal of Vacation Marketing, Vol. 12, No. 1, 5-14.

15. Garcimartin, F., Ocampos, A., Sierra, J., (2020). Impact of Covid-19 on Sponsorships in Sport: Spain, https://www.linklaters.com/en/insights/ blogs/sportinglinks/2020/may/impact-of-covid-19-on-sponsorships-inspanish-sport, (07 January 2021).

16. Horáčková A., Đurđević, D., Radnović, B., (2020). Branding the Czech Republic as a tourist destination. In: M. Ratković \& N. Perić (Eds.), Branding countries and nations: possibilities and implications (pp. 145170). Faculty of Business Studies and Law, Faculty of Strategic and Operational Management, Belgrade.

17. Jovović, D., Stojadinović-Jovanović, S., Dašić, B. (2014). Agricultural trade and financing through FDI. Economics of Agriculture, Vol. 61, No. $2,455-469$.

18. Keshkar, S, Dickson G, Ahonen A, Swart K, Addesa F, Epstein A, et al. (2021). The Effects of Coronavirus Pandemic on the Sports Industry: An Update. Annals of Applied Sport Science. Vol. 9, No. 1, http://aassjournal.com/article-1-964-en.html, (02 February 2021). 
19. Konečnik-Ruzijer, M. (2015). Brend i identitet države: Slovenija. U N. Morgan, A. Pričard \& R. Prajd (Ur.), Destinacija kao brend: upravljanje reputacijom mesta (pp. 342-353), Clio, Beograd.

20. Kos-Kavran A., Herman, D. (2020). Branding a country as a desirable touristic destination-case of Croatia. In M. Ratković \& N. Perić (Eds.), Branding countries and nations: possibilities and implications (pp. 117144), Faculty of Business Studies and Law, Faculty of Strategic and Operational Management, Belgrade.

21. Kotler, F., Gertner D. (2015). Ponovni pregled perspektiva marketinga i brendiranja mesta. U N. Morgan, A. Pričard \& R. Prajd (Ur.), Destinacija kao brend: upravljanje reputacijom mesta (pp. 51- 74), Clio, Beograd.

22. Luković, S., Stojković, D. (2020). Covid-19 pandemic and global tourism. Hotel and Tourism Management, Vol. 8, No. 2, 79-88.

23. Logovectordr.com, http://logovectordl.com/i-feel-slovenia-logovector-svg/, (18 February 2021).

24. Macmillen, D., (2011). Nation Branding in Argentina: Twenty Years on Rebranding Argentina, http://www.culturaldiplomacy.org/cultural diplomacynews/content/pdf/Cultural_Diplomacy_Outlook_Report_2011_ -_04-01.pdf, (21 February 2021).

25. Marbella International University Centre, (2020), The Impact of the Covid Crisis on the Sport Industry, https://miuc.org/impact-covid-crisissport-industry/, (16 February 2021).

26. Marcus, D. (2020). Force Majeure: The Lasting Fight In The Wake Of Coronavirus, https://www.forbes.com/sites/danielmarcus/2020/03/23/ force-majeure-the-lasting-fight-in-the-wake-of-coronavirus/?sh= 33dd369a775a, (14 February 2021).

27. Marijanović, R., Marijanović, M., Cvijić, L. (2020). Značaj antropogenih i prirodnih resursa za razvoj sportsko-rekreativnih aktivnosti u turizmu u cilju brendiranja Crne Gore. In M. Ratković \& N. Perić (Eds.), Branding countries and nations: possibilities and implications (pp. 171192), Faculty of Business Studies and Law, Faculty of Strategic and Operational Management, Belgrade. 
28. Mugo, M., Misiani, P. (2017). Applying Anholt's National Branding Model, The Case of Kenya. Business and Economics Journal, Vol. 8, No. 4, 1000335 .

29. Mulder, N. (2021). The impact of the COVID-19 pandemic on the tourism sector in Latin America and the Caribbean, and options for a sustainable and resilient recovery. International Trade series, No. 157, https://www.cepal.org/sites/default/files/publication/files/46502/S200075 1_en.pdf. (23 January 2021).

30. Olins, W., Hildret, J., (2015). Brendiranje države: juče, danas, sutra. U N. Morgan, A. Pričard \& R. Prajd (Ur.), Destinacija kao brend: upravljanje reputacijom mesta (pp. 75-92), Clio, Beograd.

31. Pavićević, A., Pavlović, M., Đoković, G. (2020). Branding of state and nation in the case of Spain. In M. Ratković \& N. Perić (Eds.), Branding countries and nations: possibilities and implications (pp. 221-242), Faculty of Business Studies and Law, Faculty of Strategic and Operational Management, Belgrade.

32. Prnjat, A. (2019). Xenophobia and Identitarian Nationalism. In V. Milisavljević \& N. Mićunović (Eds.), Xenophobia, Identity and New Forms of Nationalism (pp. 240-251). Institute of Social Sciences, Belgrade.

33. Radanović, B., Horáčková, Đurđević, D. (2020). Serbia as a brand in foreign view. In M. Ratković \& N. Perić (Eds.), Branding countries and nations: possibilities and implications (pp. 13-36), Faculty of Business Studies and Law, Faculty of Strategic and Operational Management, Belgrade.

34. Ratković, M., Dašić, D. (2018). Marketing u sportu, Visoka škola modernog biznisa, Sven, Beograd.

35. Rein, I., Shields, B. (2007) Place branding sports: Strategies for differentiating emerging, transitional, negatively viewed and newly industrialised nations. Place Branding and Public Diplomacy, Vol. 3, No. $1,73-85$.

36. Saviola, S., Marazza, A. (2013). Lifestyle Brands, Palgrave Macmillan, New York. 
37. Skoko, B., (2009). Država kao brend - upravljanje nacionalnim identitetom, Matica Hrvatska, Zagreb.

38. Stojadinović-Jovanović, S., Dašić, B. (2015). The importance of foreign direct investment for Sout East European countries agriculture. Economics of Agriculture, Vol. 62, No. 3, 661-675.

39. Sultana, S., Islam T., Islam M. (2020). Impact of Covid-19 Pandemic on Top Tourist Destinations in the World. Journal of Tourism, Hospitality and Sports, Vol. 50, 41-50.

40. Vranešević, T., Perić, N., Marušić, T. (2020). Nation brand measuremenet-important or maybe not. In M. Ratković \& N. Perić (Eds.), Branding countries and nations: possibilities and implications (pp. 63-92), Faculty of Business Studies and Law, Faculty of Strategic and Operational Management, Belgrade.

41. Vietor, R. (2010) Kako se zemlje natječu - strategija, struktura $i$ državno upravljanje u globalnoj ekonomiji. Mate D.o.o. Zagreb. 